\title{
Empowering Critical Thinking and Problem-Solving Skills During Pandemic Through Contextual Distance-Learning in Biology
}

\author{
Fitarahmawati $^{1, *}$ Suhartini $^{2}$ \\ ${ }^{1}$ Master of Biology Education, Faculty of Mathematics and Natural Sciences, Universitas Negeri Yogyakarta, \\ Indonesia \\ ${ }^{2}$ Department of Biology Education, Faculty of Mathematics and Natural Sciences, Universitas Negeri \\ Yogyakarta, Indonesia \\ *Corresponding author.Email: fitarahmawati.2019@student.uny.ac.id
}

\begin{abstract}
The 21st century requires several skills to deal with today's problems, including critical thinking and problemsolving skills. Distance learning was applied in order to avoid the transmission of Covid-19. Distance learning causes students to learn contextually from the environment directly. This article discusses the potential of contextual learning through distance learning to be applied during the COVID-19 pandemic. This research is belong to literature review to answer the problems about: 1) how contextual learning contributes to improving critical thinking and problem solving skills, and 2) how contextual learning is carried out through distancelearning. The results showed that the learning components including constructivism, inquiry, questioning, community learning, modelling, reflection, and authentic assessment can empower critical thinking core skills as well as problem solving skills. In implementing contextual distance learning must pay attention on several things: the method used must develop deep thinking skills, using synchronous and asynchronous media according to student characteristics, using learning resources by design and by utilization, maintaining the best possible communication between class members, and making clear guidance about the learning activities carried out by students.
\end{abstract}

Keywords: Contextual learning, Distance learning, Critical thinking, Problem solving

\section{INTRODUCTION}

A person's skills for life in the 21 st century can be categorized into three things: (1) skills to live and build a career, (2) skills to learn and make innovation, and (3) skills to use information media and technology[1]. Skill that needed to learn and make innovation to deal with problems in real life skills to think critically and to solve problems. These two skills are also considered as the new foundations of $21 \mathrm{st}$ century learning[1] because every day problems are growing and different from the problems of the past.

Critical thinking and problem solving skills cannot be automatically mastered by a person or student, but must be trained in students. Teachers expect students to be able to learn independently, but never or rarely teach how they actually learn. Educators must teach how to think and not how to think[2]. Therefore, the learning process in the classroom must be designed with an appropriate strategy or model.

Biology learning basically aims to teach students to obtain facts, concepts, and principles of biology through investigative or inquiry activities. Biology as a science is built on investigative activities to produce new findings using the scientific method. In order for this to be achieved, students must interact as often as possible with the phenomena of biological problems that exist in real life. Many biological problems can be found around students, including environmental pollution, health problems, forest damage, pollution, utilization of genetically modified plants, and so on. This problem can be developed to improve students' thinking power while making learning more meaningful. 
The COVID-19 pandemic has caused distance learning to be carried out to repress the spread of the Coronavirus by conducting distance learning, both by online learning, e-learning, and blended learning. Teachers experience difficulties to conduct a distance learning for example in determining learning methods, lack of access and the ability to utilize technology for learning, limited media and learning resources that are easily accessible to students, difficulties in giving feedback to students due to the time consuming to create learning content. [3]. However, on the other hand, distance learning has the opportunity to revive the learning context because students can learn from real objects in the environment where they live directly, not limited by classrooms as learning in schools. The main problem is how to coordinate and communicate effectively between teachers and students and between students so that interactions in class are maintained during distance learning. Therefore, this article discusses the potential for contextual learning to be carried out through distance learning during the COVID-19 pandemic. This study purposes to explain the potential for contextual learning to improve critical thinking and problem solving skills in the pandemic era. There are three main problems: (1) how does contextual learning contribute to improving critical thinking and problem solving skills, and (2) how contextual learning is carried out through distance-learning?

\section{METHOD}

This type of research is literature review research through various reference studies such as books, journals, proceedings, and articles that discuss contextual learning for critical thinking and problem solving skills. The journals used are from 2001-2020 and come from journals indexed by Scopus, SINTA, web of science, and / or have a DOI and contain discussions about "online learning", "e-learning", "distance learning", "remote learning "and related to" critical thinking skills "and" problem solving skills. " After that, the publication was narrowed down by selecting the categories of contextual learning approaches based on Berns \& Erickson (2001): "contextual teaching learning", "cooperative learning" "problem-based learning", "work-based learning", "project-based learning" and "service learning". The results are then analyzed in two ways: descriptive analysis of the research focus, and content analysis. The content analysis was carried out to answer the research question on how does contextual learning improve critical thinking and problem solving skills, how to make it through distance-learning. The critical thinking skills studied refer to Facione's (2011) definition of critical thinking skills, while the problem solving skills of Butterworth \& Thwaites (2013).

\section{RESULT}

\subsection{Overview}

This research method was literature review. It reviews the books, journals, proceedings, and articles that study about contextual learning in Biology, critical thinking, problem solving, and distance/online/e-learning. Data collected from 42 references and have focus as shown in table 1. Note that each reference can contain more than 1 focus, for example discussing critical thinking and problem solving, contextual learning in biology, contextual distance-learning, or a combination of more than two focus of study.

Table 1. Research focus of the references.

\begin{tabular}{|l|c|}
\hline Focus & Count of Journal \\
\hline Contextual learning & 31 \\
\hline Critical thinking & 23 \\
\hline Problem Solving & 8 \\
\hline Biology & 11 \\
\hline Distance/online/e-learning & 17 \\
\hline
\end{tabular}

\subsubsection{Contextual learning}

Contextual learning is how to make students get the meaning of learning by making the relationship between what is learned and what is happening in their life[4]. The aspects of contextual learning including constructivism, inquiry, questioning, community learning, modeling, reflection, and authentic assessment[6]. The main feature of CTL is the discovery of meaning by active learning.

\subsubsection{Critical Thinking and Problem-solving Skill}

Critical thinking is thinking by using logic deeply and thoughtfully to determine a decision [8]. People who think critically will avoid thinking mistakes by asking questions, scrutinizing assumptions, seeing things from different perspectives, and carrying out the thought process systematically. Mayer stated that problem solving is a process or series of mental operations used to move from the present situation (problem) to the desired goal. Meanwhile, Gagne defines problem solving as an activity to synthesize the knowledge they already have with the conditions they face to find solutions [11]. So, it can be concluded that 
problem solving skills emphasize the existence of behaviour obtained from the learning process combined with previous experience and lead to problem solving.

There are 4 critical thinking competencies such as reason effectively, use system thinking, make judgement and decision, and solve problem [1]. So, there is a relationship between critical thinking and problem solving skills. In the other hand, basic problem-solving skills including: 1) selecting relevant data, namely the ability to identify important and really needed data from a group of data to help solve a problem; 2) finding the right procedure to solve the problem, namely the ability to combine information from various sources to become an appropriate solution to the problem; 3 ) comparing data in different forms, namely the ability to recognize the same information so that it can be understood and selected more quickly [12] that can be taught through some activities[13].

Critical thinking skills and problem solving skills are closely related because people who can think critically [2]. and creatively [15] will be able to effectively solve problems too. By thinking critically, someone will be smart in receiving and responding to new information, accepting and expressing ideas, and finding solutions to problems. Someone who thinks critically does not easily accept information from others without first analyzing the truth. In addition, he is also not easy to accept other people's ideas spontaneously, because every idea must have advantages and disadvantages. Someone who is accustomed to thinking critically will also be more careful in formulating a solution to a problem to minimize its negative impact. Increased critical thinking has an impact on improving problem-solving

Table 2. The relationship between competencies and activities of critical thinking and problem solving skills

\begin{tabular}{|c|c|}
\hline $\begin{array}{l}\text { Critical thinking competencies } \\
\text { and activities }\end{array}$ & $\begin{array}{l}\text { Basic Problem-solving skills } \\
\text { and activities }\end{array}$ \\
\hline 1. Reason effectively & 1. Selecting relevant data \\
\hline $\begin{array}{l}\text { Using many kind of reasoning (inductive, } \\
\text { deductive, etc.) in many situation }\end{array}$ & \multirow{6}{*}{$\begin{array}{l}\text { Representing the problem, including } \\
\text { invoking appropriate context knowledge, } \\
\text { and identifying objectives and initial } \\
\text { conditions relevant to the problem; }\end{array}$} \\
\hline 2. Use systems thinking & \\
\hline $\begin{array}{l}\text { Analyzing the interaction of each components } \\
\text { to make a result }\end{array}$ & \\
\hline 3. Make judgment and decision & \\
\hline $\begin{array}{l}\text { Analyzing and evaluating states, proof, } \\
\text { arguments, and belief effectively }\end{array}$ & \\
\hline $\begin{array}{l}\text { Analyzing and evaluating some alternative } \\
\text { points of view }\end{array}$ & \\
\hline $\begin{array}{l}\text { Synthesizing and relating information and } \\
\text { reasoning }\end{array}$ & 2. Finding the right procedure to solve the problem, \\
\hline $\begin{array}{l}\text { Construing information and making } \\
\text { conclusions based on analysis }\end{array}$ & \multirow{2}{*}{$\begin{array}{l}\text { Searching for solutions including refining } \\
\text { goals and developing action plans to } \\
\text { achieve goals, }\end{array}$} \\
\hline $\begin{array}{l}\text { Critically reflecting the learning experiences } \\
\text { and processes }\end{array}$ & \\
\hline 4. Solve problems & 3. Comparing data in different forms \\
\hline $\begin{array}{l}\text { Solving varieties of unpopular problems in } \\
\text { different ways }\end{array}$ & \multirow[t]{2}{*}{$\begin{array}{l}\text { Implementing the solution/action plan and } \\
\text { evaluating the results }\end{array}$} \\
\hline $\begin{array}{l}\text { Identifying and asking core of question to } \\
\text { clarify many kinds of points of view and to get } \\
\text { the best solution }\end{array}$ & \\
\hline
\end{tabular}


abilities [15]. Through contextual learning strategies, students are equipped with higher-order thinking skills through the process of identifying and analyzing problems and learning activities that make learning more effective [16]. There are several similarities in activities undertaken to develop critical thinking and problem solving skill as shown in table 2 .

\subsection{How does contextual learning contribute to improving critical thinking and problem solving skills?}

The purpose of studying Biology is to teach or train students to obtain facts, concepts, and principles of biology through investigative or inquiry activities. The role of biology education is to increase biological literacy and give support to tackle problems of everyday life involving biological knowledge [14]. Students need to be guided so that they are skilled in thinking critically about the phenomena and problems that occur in their environment so that they can easily find solutions to these problems. So, in Biology learning, critical thinking and problem solving skills are very important for students to master, not only to face the problems in learning activity at school, but also in order to face the real life with complex problems.

There are seven components in CTL and their relation to the development of critical thinking as shown in table 3. CTL emphasizes the relationship between topics covered in learning and real life situations. Teachers can also use learning resources, learning media, or teaching materials related to real life. The existence of a link between what is learned and real life causes students to better interpret the learning process. Students can see various problems in their environment, review the material studied at school, then think critically by comparing whether there are things that are unusual, interesting, contradictory, or are looking for solutions with the knowledge gained.

Problem-solving skills emphasize the existence of behaviours that are acquired from the learning process combined with previous experiences so that they are

Table 3. Components of CTL and their relation to the development of critical thinking and problem solving skills

\begin{tabular}{|c|c|c|}
\hline $\begin{array}{l}\text { Components of } \\
\text { CTL }\end{array}$ & Definition & $\begin{array}{l}\text { Core Critical Thinking Skills } \\
\text { Developed }\end{array}$ \\
\hline \multirow[t]{2}{*}{ Constructivism } & $\begin{array}{l}\text { Constructing knowledge by comparing new information with } \\
\text { prior knowledge[5] }\end{array}$ & Analysis, Evaluation \\
\hline & $\begin{array}{l}\text { Experimenting with new things and internalizing the newly } \\
\text { acquired information with old knowledge [5] }\end{array}$ & Inference \\
\hline Inquiry & Conducting research to get a new fact/concept/principle & $\begin{array}{l}\text { Interpretation, Analysis, } \\
\text { Inference, } \quad \text { Evaluation, } \\
\text { Explanation }\end{array}$ \\
\hline Questioning & $\begin{array}{l}\text { Awakens students' reasoning power and is aimed at building } \\
\text { higher order thinking skills) [5] }\end{array}$ & $\begin{array}{l}\text { Analysis, Explanation, } \\
\text { Evaluation, Self-regulation }\end{array}$ \\
\hline \multirow[t]{2}{*}{$\begin{array}{l}\text { Learning } \\
\text { community }\end{array}$} & $\begin{array}{l}\text { Learn from each other in small groups and play a role in } \\
\text { completing tasks [5], }\end{array}$ & Evaluation, Explanation \\
\hline & $\begin{array}{l}\text { Contemplate and think deeply to increase self-consciousness } \\
\text { and metacognition [17] }\end{array}$ & Self-regulation \\
\hline Modelling & $\begin{array}{l}\text { Presenting real-life problems so the students are required to } \\
\text { think from various points of view [18] }\end{array}$ & Analysis, Inference \\
\hline Reflection & $\begin{array}{l}\text { Providing an environment that supports independent learning } \\
\text { so the students must know their strengths and weaknesses to } \\
\text { build their learning strategy [5] }\end{array}$ & Self-regulation \\
\hline $\begin{array}{l}\text { Authentic } \\
\text { assessment }\end{array}$ & $\begin{array}{l}\text { Measuring what students can do in applying knowledge and } \\
\text { in higher order thinking through various assessment } \\
\text { techniques [7] }\end{array}$ & Explanation, Self-regulation \\
\hline
\end{tabular}


in accordance with the constructivist components that underlie CTL. CTL characteristics include interdisciplinary learning, problem-based, and external context. Students must be able to see a problem in real life from various points of view and various disciplines in order to better understand the problem. Good understanding will make students wiser in responding to problems and thinking creatively to solve these problems. In addition, problem solving skills require a solution to a problem so that it can be integrated with the authentic assessment component in CTL.

\subsection{How is contextual learning carried out by distance learning?}

During a pandemic, learning is done using a distance learning method. Students recommend various methods for distance learning including: faceto-face limited person learning, ICT-based learning, and various other lessons that can improve student motivation [23]. But, the preference for applications used for distance learning is dominated by reasons of interest and personal, financial, and liking factors [24]. Therefore, the teacher must develop learning strategies that students can do at home by considering the available information and communication technology, the type of material, the activities to be carried out, the goals to be achieved and the ease and convenience of use.

Table 4 presents some studies conducted by several practitioners on how contextual learning is done by using distance learning, online learning, or elearning. This type of contextual learning refers to the contextual learning of Berns \& Erickson (2001) which includes Problem Based Learning, Cooperative Learning, Project-Based Learning, Service learning, and Work-based learning and Contextual Teaching Learning as its old name.

In Biology learning, there are many problems that can be used as a means of developing critical thinking and problem solving skills, for example the problem of environmental change, the Coronavirus pandemic, the use of drugs and cosmetics in everyday life, genetically modified plants, and so on. On the table above, contextual learning not only applied on Biology but it has potential to be applied in Biology. Based on the analysis, there are several points that need to be considered using distance learning to become more contextually: (1) Learning media. The challenge to foster deep and meaningful knowledge through web-based learning because learning via the web is also related to the context of ICT era. It is also necessary to use synchronous and asynchronous media to adapt to the material and student characteristics and for easy access; (2) Learning resource. To connect students with real life problems, it is also necessary to use learning resources by utilization or authentic materials [35]; (3) Communication. teacher guidance and leadership in group work is still needed, and is proven to increase students' level of critical thinking and problem solving skills. The teacher is obliged to guide thinking reflection and feedback on student learning outcomes. (4) Explanation. Brief guidance about the activities that will be undertaken by students and the deadlines used to complete the assignment

It also stated by Waldner (2012) that suggests criteria for good e-service learning according to three aspects, namely technology (training for teachers, students, and education providers, combining synchronous and asynchronous methods, experiments before real learning, assessing the ability of students and educational partners), communication (appropriate explanation, open access, grouping in the LMS, and introduction of class members), and learning design (linkage of service with learning objectives, reflection, reporting, and feedback)[37].

The implication of this research is the need for further experimental studies on various kinds of contextual learning methods that can be used in distance learning to improve critical thinking and problem solving skills. Various methods other than those described above may also be a solution for quality learning so that further research is needed. In addition, it is also necessary to examine the effectiveness of the method used through distance learning compared to learning in the classroom.

\section{CONCLUSION}

Biology as a science emphasizes research activities that use scientific methods with a scientific attitude to get new inquiry or concepts. There are many problems found in students' daily lives that can be studied to find solutions and build student competence. Critical thinking and problem solving skills should be taught in schools and designed by teachers in context and competency-based learning, not content-based. Contextual learning has the opportunity to improve critical thinking and problem solving skills because, students can build their cognitive structures starting from what they already know, what they just know from learning, to what they can do, and build their emotional because learning is based on what they know actually they learn in everyday life. The results showed that the learning components including constructivism, inquiry, questioning, community learning, modelling, reflection, and authentic 
Table 4. Research about contextual learning to improve critical thinking and problem solving skills.

\begin{tabular}{|c|c|c|}
\hline $\begin{array}{l}\text { Contextual Learning } \\
\text { Approach }\end{array}$ & Author & $\overline{\text { Results }}$ \\
\hline $\begin{array}{l}\text { Contextual Teaching } \\
\text { and Learning }\end{array}$ & $\begin{array}{l}\text { Suryawati, Osman \& Meerah . } \\
2010 \text { [6], Wahyuningtyas \& } \\
\text { Wuryadi, } 2018 \text { [15], Suryawati \& } \\
\text { Osman. } 2018 \text { [16], Bustami, et al. } \\
2020 \text { [19], Hasruddin, Nasution \& } \\
\text { Rezeqi. 2015 [20] } \\
\text { Bustami \& Afriani. } 2018 \text { [21] }\end{array}$ & $\begin{array}{l}\text { The field research prove that the use of CTL in } \\
\text { Biology learning can enhance critical thinking skill } \\
{[15][16][19][20][21] \text { and also empower problem }} \\
\text { solving skills [6][15]. By connecting what is learned } \\
\text { and problems in real life, students can find the } \\
\text { meaning of learning, broaden their horizons and } \\
\text { skills, as well as a good attitude, which is a condition } \\
\text { for solving problems [6]. }\end{array}$ \\
\hline $\begin{array}{l}\text { Problem Based } \\
\text { Learning }\end{array}$ & $\begin{array}{l}\text { Lukitasari, et al., } 2019 \text { [27] Buheji } \\
\text { \& Buheji, } 2020 \text { [28] Bruna, et al., } \\
2020 \text { [35]. }\end{array}$ & $\begin{array}{l}\text { Blended-PBL improves critical thinking skills because } \\
\text { it makes students understand the context of the } \\
\text { concepts being taught, as evidenced by the } \\
\text { existence of explanations about the answers they } \\
\text { made [27]. PBL also can improve self-directed } \\
\text { learning [35] that can lead to the improvement of } \\
\text { problem solving skills [28][35] }\end{array}$ \\
\hline Cooperative Learning & $\begin{array}{l}\text { Heru, et al. } 2015 \text { [22] Dewi et al } \\
\text { (2019) [30] Cheng et al, } 2019 \text { [29] } \\
\text { Espey, } 2017 \text { [31] Erdogan, } 2019 \\
\text { [32] }\end{array}$ & $\begin{array}{l}\text { Cooperative learning can improve critical thinking } \\
\text { skills [29][30][31][32] with collaboration and } \\
\text { interaction between group members as the key to } \\
\text { successful learning [31][32]. The method mediated } \\
\text { by e-learning platform also enhanced problem } \\
\text { solving skill [22][30]. }\end{array}$ \\
\hline $\begin{array}{l}\text { Project-Based } \\
\text { Learning \& Service } \\
\text { learning }\end{array}$ & $\begin{array}{l}\text { Athamneh \& Ashraf, } 2020 \text { [34], } \\
\text { Becnel \& Moeller (2016) [36], } \\
\text { Waldner, et al, } 2012 \text { [37], Helms, } \\
\text { et al, } 2015 \text { [38], Molee, et al., } \\
2010 \text { [39], McGorry, } 2012 \text { [40]. }\end{array}$ & $\begin{array}{l}\text { Project-based learning, as well as services learning, } \\
\text { can increase critical thinking and problem solving } \\
\text { skills because students can meet and try to solve the } \\
\text { authentic problems in the real world } \\
{[34][36][37][38][39][40] \text {. However, lab-based }} \\
\text { project-based learning is so limited to be done in a } \\
\text { pandemic situatiom, so it can be replaced by } \\
\text { mentor-guided critical thinking exercises with } 5 \\
\text { steps: reading, stating the problem, proposing a } \\
\text { hypothesis, literature research/critical reflection, } \\
\text { conclusion [34] }\end{array}$ \\
\hline Work-based learning & $\begin{array}{l}\text { Cheng, et al., } 2020 \text { [41]. Wagner } \\
\text { \& Strach, } 2019 \text { [42] }\end{array}$ & $\begin{array}{l}\text { Work-based learning applies the principles of } \\
\text { experiential learning. If students get direct } \\
\text { experience to gain knowledge through learning, } \\
\text { through cooperation, reflection, questioning, and } \\
\text { action, they will find it easier to apply the knowledge } \\
\text { gained and increase their ability to reflect and think } \\
\text { critically [41]. To increase the consistency and quality } \\
\text { of work-based learning, educational institutions can } \\
\text { make curriculum changes and innovate in } \\
\text { conducting learning and evaluation [42]. }\end{array}$ \\
\hline
\end{tabular}


assessment can empower critical thinking core skills that also lead to problem solving skills. Contextual learning during a pandemic is carried out by utilizing the surrounding environment as the main learning resource with the help of ICT as a liaison between teachers and students and students and students. Teachers must develop learning strategies that students can do at home by considering the availability of information and communication technology, types of material, activities to be carried out, goals to be achieved and ease and convenience of use. Some things that need to be considered in conducting contextual distance learning include: the method used must develop deep thinking skills, using synchronous and asynchronous media according to student characteristics, using learning resources by design and by utilization, maintaining the best possible communication between class members, and making clear guidance about the learning activities carried out by students.

\section{REFERENCES}

[1] B. Trilling, C. Fadel, 21st Century Skills: Learning for Life in Our Times, John Wiley \& Sons, 2009.

[2] L.G. Snyder, M-J. Snyder, Teaching critical thinking and problem solving skills, The Delta Pi Epsilon Journal 60 (2008) 90-91.

[3] R.S. Putri, A. Purwanto, R. Pramono, M. Asbari, L-M. Wijayanti, C-C. Hyun, impact of the COVID-19 pandemic on online home learning: an explorative study of primary schools in Indonesia, International Journal of Advanced Science and Technology 29 (2020) 4816.

[4] E.B. Johnson, Contextual Teaching and Learning 2nd Ed., Corwin Press, 2002.

[5] R.G. Berns, P.M. Erickson, Contextual Teaching and Learning: Preparing Students for the New Economy, National Dissemination Center for Career and Technical Education, 2001.

[6] E. Suryawati, K. Osman, T.S.M. Meerah, The effectiveness of RANGKA contextual teaching and learning on students' problem solving skills and scientific attitude, in: Procedia Social and Behavioral Sciences, vol. 9, Elsevier, Amsterdam, 2010, p. 1717-1721. DOI: https://doi.org/10.1016/j.sbspro.2010.12.389.

[7] C.C. Hudson, V.R. Whisler, Contextual teaching and learning for practitioners, Systemics, Cybernetics and Informatics 6(4) (2008) 54-58.
[8] R.H. Ennis, The nature of critical thinking: an outline of critical thinking disposition and abilities, Presentation at the Sixth International Conference on Thinking at MIT, Cambridge, MA, July 1994, 2011.

[9] P.A. Facione, Critical Thinking: What It Is and Why It Counts, Insight assessment, 2015.

[10] R.H. Huang, D.J. Liu, N. Amelina, J.F. Yang, R.X. Zhuang, T.W. Chang, W. Cheng, Guidance on Active Learning at Home During Educational Disruption: Promoting Student's Self-Regulation Skills During COVID-19 Outbreak, Smart Learning Institute of Beijing Normal University, 2020 .

[11] W-R. Foshay, J. Kirkley, Principle for Teaching Problem Solving Technical Paper, The Roach Organization Inc., 2003.

[12] J. Butterworth, G. Thwaites, Thinking Skills: Critical Thinking and Problem Solving 2nd Ed, Cambridge University Press, 2013.

[13] W-R. Foshay, J. Kirkley, Principles for Teaching Problem Solving, The Roach Organization Inc., 1998.

[14] A. Laius, A. Post, M. Rannikmäe, Promoting biological literacy skills of gymnasium students during the operation of a new competence-based biology curriculum, in: Challenges in Biology Education Research, Karlstad University Printing Office, 2017.

[15] R.S. Wahyuningtyas, Wuryadi, The influence of contextual teaching and learning (CTL) towards chritical thinking and problem solving ability on skeletal system materials, in: Proceeding of International Conference on Research, Implementation and Education of Matematics and Science 5th, Faculty of Mathematics And Natural Sciences Universitas Negeri Yogyakarta, Yogyakarta, 2018, pp. 122. DOI: https://doi.org/10.1063/1.5062828

[16] E. Suryawati, K. Osman, Contextual Learning: Innovative Approach towards The Development of Students' Scientific Attitude and Natural Science Performance, Eurasia Journal of Mathematic Science and Technology Education 14 (2018) 61-76. DOI: https://doi.org/10.12973/ejmste/79329.

[17] I.J. Quitadamo, C.L. Faiola, J.E. Johnson, M.J. Kurtz, Community-Based Inquiry Improves Critical Thinking in General Education Biology, 
CBE-Life Sciences Education 7 (2008) 327-

337. DOI: https://doi.org/10.1187/cbe.07-11$\underline{0097}$

[18] K. Chamany, D. Allen, K. Tanner, Making Biology Learning Relevant to Students: Integrating People, History, and Context into College Biology Teaching, CBE-Life Sciences Education 7 (2008) 267-278. DOI: https://doi.org/10.1187/cbe.08-06-0029

[19] Y. Bustami, Leliavia, M. Elisabeth, A. Gandasari. D. Ratnasari, Contextual Teaching Learnıng in Human Digestive System: The Contribution of Critical Thinking Skills, Biosfer: Jurnal Pendidikan Biologi 13 (2010) 101-113. DOI: https://doi.org/10.21009/biosferjpb.v13n1.101$\underline{113}$

[20] Hasruddin, M-Y. Nasution, S. Rezeqi, Application of Contextual Learning to Improve Critical Thinking Ability of Students in Biology Teaching and Learning Strategies Class, International Journal of Learning, Teaching and Educational Research 11 (2015) 109-116.

[21] Y. Bustami, D. Syafruddin, R. Afriani, The Implementation of Contextual Learning to Enhance Biology Students' Critical Thinking Skills, Jurnal Pendidikan IPA Indonesia 7 (2018) 451-457.

DOI: https://doi.org/10.15294/jpii.v7i4.11721

[22] S. Heru, M-S-F. Alimi, S. Alimah, F.H. Kurniawan, Implementing Contextual Biology Game Learning (CBGL) in Digital Era with Pterodovela In Smartphone to Improving Senior High School Student's Abilities in Learning Diversity of Bryophyta and Pterodophyta in Indonesia, PEOPLE: International Journal of Social Science (2015) 197-212.

[23] E. Koçoğlu, D. Tekdal, Analysis of Distance Education Activities Conducted during Covid-19 Pandemic, Educational Research and Reviews 15 (2020) 536-543. DOI: https://doi.org/10.5897/ERR2020.4033

[24] Husni, D-S. Munandar, A. Azis, D. Darisman, S.S. Rizal, Preferable Applications for HomeBased Learning During The Coronavirus (COVID-19) Outbreak in Indonesia Islamic Higher Education, International Journal of Scientific \& Technology Research 9 (2020) 281284.
[25] Kardoyo, A. Nurkhin, Muhsin, H. Pramusinto, Problem-Based Learning Strategy: Its Impact on Students' Critical And Creative Thinking Skills, European Journal of Educational Research 9 (2020) 1141-1150. DOI: https://doi.org/10.12973/eu-jer.9.3.1141

[26] H.Y. Sung, G.J. Hwang, H-S. Chang, An Integrated Contextual and Web-Based Issue Quest Approach to Improving Students' Learning Achievements, Attitudes and Critical Thinking, Educational Technology \& Society 18 (2015) 299-311.

[27] M. Lukitasari, I. Purnamasari, S. Utami, A. Sukri, Blended-Problem-Based Learning: How Its Impact on Students' Critical Thinking Skills?, Jurnal Pendidikan Biologi Indonesia 5 (2019) 425-434.

DOI: https://doi.org/10.22219/jpbi.v5i3.10048

[28] M. Buheji, A. Buheji, Characteristics of Problem-Based Learning' in Post-COVID-19 Workplace, Human Resource Management Research 10 (2020) 33-39. DOI: https://doi.org/10.5923/j.hrmr.20201002.02

[29] S.C. Cheng, L.C. Huang, C.L. Lai, Effects of The Group Leadership Promotion Approach on Students' Higher Order Thinking Awareness And Online Interactive Behavioral Patterns in A Blended Learning Environment, Interactive Learning Environments (2019) 246-263. DOI: https://doi.org/10.1080/10494820.2019.1636075

[30] N-R. Dewi, L. Maghfiroh, L. Nurkhalisa, I. Dwijayanti, The Development of ContextualBased Science Digital Storytelling Teaching Materials to Improve Students' Critical Thinking on Classification Theme, Turkish Science Education 16 (2019) 364-378. DOI: https://doi.org/10.12973/tused.10288a

[31] M. Espey, Enhancing Critical Thinking Using Team-Based Learning, Higher Education Research \& Development 37 (2017) 1-15. DOI: https://doi.org/10.1080/07294360.2017.1344196

[32] F. Erdogan, Effect of Cooperative Learning Supported by Reflective Thinking Activities on Students' Critical Thinking Skills, Eurasian Journal of Educational Research 80 (2019) 89112.

DOI: https://doi.org/10.14689/ejer.2019.80.5

[33] I.G.A.A.S. Diarini, M.F.B. Ginting, I.W. Suryanto, Penerapan Model Pembelajaran 
Project Based Learning Berbasis Lesson Study Melalui Pembelajaran Daring untuk Mengetahui Kemampuan Berfikir Kritis dan Hasil Belajar, Ilmu Sosial dan Humaniora 3 (2020) 253-265.

[34] K. Athamneh, S.S. Ashraf, Never Let A Crisis Go to Waste: Repurposing Independent Research Projects to Enhance Students' Critical Thinking Skills, Biochemistry and Molecular Biology Education (2020) $\quad 1-3$. DOI: https://doi.org/10.1002/bmb.21401

[35] C.E. Bruna. N.A. Valenzuela, D.V. Bruna, A.L. Rodrıguez, C.G. M'arquez, Learning Metabolism by Problem-Based Learning through The Analysis of Health or Nutrition Articles from The Web in Biochemistry, Food Science Education (2019) 1-8. DOI: https://doi.org/10.1111/1541$\underline{4329.12156}$

[36] K. Becnel, R.A. Moeller, Community-Embedded Learning Experiences: Putting The Pedagogy of Service-Learning to Work in Online Courses, Open Learning: The Journal of Open, Distance and e-Learning 37 (2016) 56-65. DOI: http://doi.org/10.1080/02680513.2016.1265443

[37] L-S. Waldner, S.Y. McGorry, M.C. Widener, EService-Learning: The Evolution of ServiceLearning to Engage A Growing Online Student Population, Higher Education Outreach and Engagement 16 (2012) 123.

[38] M-M. Helms, R-M. Rutti, A.A. Hervani, J. LaBonte, S. Sarkarat, Implementing and Evaluating Online Service Learning Projects, The Journal of Education for Business 90 (2015) 369-378.

DOI: http://dx.doi.org/10.1080/08832323.2015.10741 $\underline{50}$

[39] L.M. Molee, M.E. Henry, V.I. Sesa, E.R. McKinney-Prupis, Assessing Learning in Service-Learning Courses through Critical Reflection, Journal of Experiential Education 33 (2010) 239-257. DOI: https://doi.org/10.1177/105382590113300304

[40] S.Y. McGorry, No Significant Difference in Service Learning Online, Journal of Asynchronous Learning Networks 16 (2012) 4554.

[41] Y.C. Cheng, L.C. Huang, C.H. Yang, H.C. Chang, Experiential Learning Program to Strengthen Self-Reflection and Critical Thinking in Freshmen Nursing Students during COVID-
19: A Quasi-Experimental Study, International Journal of Environmental Research and Public Health $17 \quad$ (2020) 1-8. DOI: https://doi.org/10.3390/ijerph17155442

[42] A. Wagner, P. Strach, Internships and applied work-based learning experiences in higher education, New Directions for Higher Education 188 (2019) 51-59. DOI: https://doi.org/10.1002/he.20345 